\title{
Concept and Structure of a Phenomenon of Spirituality in Modern Religious Studies
}

\author{
Ruslan A. Kosolapov and Vladimir I. Kuybar* \\ Irkutsk State University \\ 1 Karl Marx Srt., Irkutsk, 664003, Russia
}

Received 26.04.2015, received in revised form 21.05.2015, accepted 14.07.2015

The social and philosophical understanding of the nature of spirituality which is considered as system of stable relations of the person and society, as a way of the organization and existence of the valuable beginning in the content of universal life is given. Its religious and secular interpretation, methodology and efficiency in knowledge of two types of society are investigated: consumption and creation in the conditions of modern globalization.

Keywords: spirituality, virtual reality, social, secular, religious, orthodox outlook, consumer society, society of creation, globalization.

DOI: 10.17516/1997-1370-2015-8-9-1973-1978.

Research area: philosophy.

\section{Introduction}

Contradictory nature of modern social development, its dynamic global activity put forward new tasks in the field of philosophical judgment of the processes happening in mass public consciousness. One of indicators of this movement is revival of interest in the perspective connected with the spirituality phenomenon nature, with its place and a role in system of social being, both secular, and religious. The opposition aggravation between the personality and society, outlined in the first decade of the XXI century, staticizes a problem of intrinsic filling of spirituality as attribute and the mechanism of reproduction of global activity of society.

Despite that the spirituality subject a keynote passes through all history of the Russian philosophical thought, a subject of the scientific research analysis it became, with rare exception, only in the last two decades. This circumstance is caused by the ideological and socio-political reasons (is more exact obstacles). An important role to excitement of interest in this problem updating played it a specified period. Deep transformation of sociocultural space of Russia led to acute world outlook crisis, initiated public need for the person spiritual, splash in appeals to a spirituality subject in general.

\section{Point of view}

For us the full is such understanding of spirituality at which there is an interiorization and an eksteriorization of moral values and spiritual elements of culture in a zhiznetvorchestvo of

(C) Siberian Federal University. All rights reserved

* Corresponding author E-mail address: naukaitfk@mail.ru 
the personality. The Smysloobrazuyushchy core of spirituality is its valuable and semantic filling penetrating moral and ethical intellectual (cognitive) and art and esthetic began, reducing them in a uniform axiological point of spiritual life of the person ( Katunina, 2005; Shtumpf, 2010).

As priority in structural hierarchy of spirituality it is necessary to recognize the moral and ethical beginning. It acts as the indicator defining fullness of social and individual life as the morals are one of the main mechanisms not only regulation of the relations, but also "spiritualizing" of the person. In the course of finding of knowledge, a choice of living position and ideals, people comprehends and worries not only the personal life experience. Sometimes the meaning of life can be found only when it we don't realize any more. But experience of the destiny gives dynamic rise to search of new values and knowledge, protects persons from degradation. Therefore the maintenance of spirituality as moral basis not only and not so much individual, how many social life is so significant. It integrates thought, knowledge and experiences with behavior action.

The inclusiveness in the valid, original process of public life forces its participants to choose system of the vital strategy and values aimed at improvement of life. And here spirituality can and has to carry out a role of the valuable and moral vector of subjective and social programs of human activity possessing huge potential for transformation possible in real-life.

In our opinion, the potential condition of spirituality of the person and society in the modern world can be opened, having presented it as the special spiritual virtual ( Frankl, 1990; Biryukova, 201)]. The matter is that the term "virtual reality" which arose in a physics subsoil in the philosophical and theoretical plan promptly expands space of the action and there is an element of the categorial device of many sciences (Kuybar, 2006, 2009). The virtual reality is sensually reliable, incorporeal, it is given to the person only in his feelings, this subjective mental experience of the designed, possible world. It is known that objects of virtual reality are perceived by the subject as real-life. But they arise and exist (prove) only in the act and time of interaction of the person with technical means as a way of intersubject communication. Their feature consists that they don't exist potentially in other particles as physical elements, but are shown only in imagination of the person and carry, like a dream, ephemeral character (Menchikov, 1999). Virtual objects exist only "here" and "now", carrying out the functions during an interaktion and modification of objects by means of mental immersion to the virtual world. They never appear in entry and final conditions of virtualization.

In this light researches of R. Feynman who by practical consideration in the field of quantum physics comes to a conclusion that process which can arise only owing to temporary violation of conservation laws is called as virtual process are very actual (Feynman,1978). These words confirm our doubts in possibility (degree) of safety of the human person as integrity. Moreover, it becomes clear that interaction of the person with virtual reality has strong and not harmless impact on mentality, a sociality and an orientation of activity of the modern person.

However it is necessary to recognize that the idea about the virtual nature of spirituality isn't deprived of the bases. Unalterability of emergence and existence of this phenomenon in the act and time of interaction with the person acts as the starting parcel explaining an admissibility of this assumption. These circumstances set conditions of presence or lack of spirituality in real life. The valid life means the appeal to spiritual intensions, concepts and standards not 
as obligation determination, and only as the duty caused by a set of potential elections and opportunities. Spirituality it is possible to present spaces of opportunities which either receive in the form, or don't receive realization depending on concrete and real conditions of life. And here as decisive factors spiritual and moral character of the acting personality, a difficult combination of properties of the person and features of external conditions of his activity act. Only in the course of realization of the opportunities spirituality turns from virtual object into the real-life principle.

In this measurement we find it possible to define the concept "spirituality" how the social and philosophical category designating a certain party of virtual reality which in an act integrates and generates the sum of social qualities of the subject: philanthrophy, honesty, conscientiousness, justice, a pokayannost and others which in total acted as the tool of concrete definiteness (potrebny model) in the organization of public life of people. These properties of the personality, according to this or that religious or secular doctrine, as the principles or precepts are used by social communities as the invariable norms, rules, a ban and permissions directed on "designing" of human community ( Abramov, Kosolapov, Kuybar, 2015).

It is necessary to add to the told that the cultural tradition of the Russian people is defined by humanistic bases of his outlook. The last mean philanthrophy, moral, truth, beauty, perfection, harmony, love, belief, hope as the highest, immutable bases of life. Spiritual filling of the designated tradition is connected with potential possibility of its manifestation in life of each person and further - society. It confirms the fact of presence of the humanistic beginning in a phenomenon spirituality, revealing in variety of the existing opportunities, values, duties doing human life of a worthy appreciation (Zinrov, 2006; Homuttsov, 2009; Cozlova, 2012).
The humanistic beginning is defining in the comparative analysis of secular and religious interpretation of spirituality. These positions, having many common features, nevertheless differ. Their main difference is shown in the purposes pursued by them, tasks, the mechanism and tools of creation of the humanitarian circle of the subject and, further, society.

The secular position adheres to the point of view of "harmonious development of the person". It is directed on uniform maturing of all forces and abilities of the person in process of his formation and education. The intellectual beginning and democratic principles in this case belong to basic values: freedom, ethical standards, advantage, benefit, culture, independent thinking. The purpose of a secular position is creation of the general humanitarian environment of human community. Spirituality in this case acts as the tool of a humanization of the subject and society. It defines the general humanistic orientation of development of civil society. As the mechanism of implementation of this purpose the legal system governing the civil relations in the state acts.

Thus, the concept "secular spirituality" of knowledge is the social and philosophical category designating a certain order of the composed social qualities of the person (freedom, advantage, the benefit, etc.) which it uses as the instrument of socialization for the purpose of achievement of personal success which are clear and also following which is used by other participants of the social movement, but, isn't rigid if weakens action of the principle: "I" at the expense of another".

The religious position relies on idea (law) of a hierarchical structure of all forces of the person both biological, and sincere and spiritual, at the same time coordinated among themselves. In this regard we will note that the understanding of a phenomenon of spirituality in Orthodoxy 
is unique, and significantly differs as from understanding of spirituality in other religions, and in understanding philosophical. Because spirituality doesn't exist in an abstract look, and is realized through the concrete carrier - the person, the orthodox divinity at first does the detailed analysis that there is a person, and only then considers problems of spirituality and its value for the person.

\section{Example}

And the first problem arising thus - than two similar terms used during creation of the person differ from each other: on an image, and on similarity Supreme. At first sight both terms transfer some certain compliance to the original on sense, then two words why are used? Here the Bible text doesn't give the clear answer.

Image - it's given (at creation) to Adam various abilities distinguishing it from an unreasonable creature and pulling together it good luck (freedom, a rationality, creativity, etc.). The prelate Gregory the Theologian and Saint John of Damascus called in a way soul of the person, introducing the idea that the God's image makes the nature of soul human.

Similarity - the objectives of human existence which is achieved by effort of own will in virtuous life - a bogoupodobleniye.

It isn't necessary to separate these two concepts from each other since they though have the shades, but are inseparably linked with each other. "Image" reminds mainly of gift by God to the person, "similarity" - of a spiritual and moral duty of the person to store this gift and to promote its pro-shine. Likening to God is possible only on "soil" of an image. Similarity is disclosure of an image.

Besides, the concept of an image gained developments after coming to Jesus Christ's world since Christ is "an image of God Invisible" (2 Boxes. 4, 4; Stake. 1, 15); "shine of glory and image of its form" (Evr. 1, 3). "the first person Adam became hulk living, and the last Adam is spirit life-giving” (1 Boxes. 15, 45). Christ is a true image of God, and, therefore, the bogoupodobleniye is an acceptance of the Christ's image, and together with it and spirit of life (spirit life-giving). In communication with Christ of people restores in itself the God's image dulled by a sin.

Summing up the result of a subject of creation of the person, it should be noted that according to orthodox dogma, the person to be created in the last day creations of the World, and the latest, i.e. is the highest and perfect creation. According to the person has the most difficult structure: the body has a terrestrial origin, and Spirit of life-giving a body, and made his Person, occurs from God. Respectively in the Person are combined, or better to say that in the Person two worlds the world a terrestrial and inner world unite. And from that how successfully the person realizes this function of association degree of his spirituality, as activities for a spiritualizing of the surrounding terrestrial world, and for enhancement of God's Spirit in itself, i.e. to strengthening of the personal communication with an inner world depends.

Religious approach sees relationship of the person with different levels of integrity from the point of view of his subordination Supreme. The person is created by it and undoubtedly is only a God's creation, proportioning all the words, affairs and acts to his will and a favoring. The purpose of this position the general tendency to spiritual coexistence and a unification, achievement of general sanctity seems. The mechanism of implementation of this purpose is the spiritual life of society including and secular level of a social humanization. As the instrument of achievement of religious spirituality the conciliarity meaning integrity 
and internal hierarchy of intrinsic forces as separately taken subject, and a unification of all society in aspiration to general (desirable) spiritual integrity acts.

\section{Conclusion}

In this article authors the concept "Conciliarity" - treat as the social and philosophical category indicating the social mechanism of functioning of religious spirituality as a substantial kernel of world outlook unity of confessional community. The philosophical essence of concept of church conciliarity consists that modern completeness and integrity of spiritual unity of persons in a bogochelovechesky organism of Church have the basis in correlation of each personality directly with Christ. Cathedral unity of individuals thus personally both in the spiritual sources, and in the dynamics. Its source is understanding and alternation by the person of the unique originality in the face of the Absolute and, thus, conducts the individual to perfect completeness personal life, i.e. is ontologic ensuring their perfect spiritual unity [8; Kanapatsky]. Conciliarity as the instrument of religious expression of spirituality many centuries it was used in the
Russian cultural tradition, achievements of a spiritual unification of our people. From here it is possible to conclude that the category "religious spirituality" in social and philosophical knowledge indicates the cathedral unity of persons in a bogochelovechesky organism of Church based on idea of local life in God and good luck by means of unconditional trust to canons of the accepted dogma, continuous following to the principle: "I" together with others".

The told allows to differentiate methodologically in the academic interests ideas of spirituality of society in the conditions of modern globalization. The matter is that they rely on understanding of spirituality as the methodological tool of knowledge and allow to postulate two types of global community: "consumer society", which natural state - a condition of hostility, rivalries, suppression of interests of the neighbor in interests of personal success by the principle: "I" at the expense of another"; and "society of creation" which naturalness is shown in the form of improvement of the humanitarian relations, compassion, purity of conscience and others by the principle "Ya" together with others".

\section{References}

1. Katunina N. S. Nature of Spirituality of the Person (gnoseological aspect): abstract of the thesis diss. for Dr.s Philosophy, Moscow, 2005, 38 p.

2. Shtumpf S. P. Spirituality. Axiological orientation and sociocultural nature of a phenomenon: monograph. Krasnoyarsk: Publishing house Krasnoyarsk state pedagogical university of V.P. Astafyev, 2010, $176 \mathrm{p}$.

3. Frankl V. Peoplek in search of sense. Moscow, Progress, 1990. P. 140-146.

4. Biryukova E. A. Spiritual and moral improvement of the person: analysis of essence and virtual and figurative forms: abstract of the thesis diss. for Dr.s Philosophy, Tula, 2010, $50 \mathrm{p}$.

5. Kuybar V. I. To a question of virtual forms of social interactions in information society. The Bulletin of Krasnoyarsk State University. Humanities. - Krasnoyarsk, 2006(6). P. 22-27.

6. Kuybar V. I. Concept "information and virtual reality" as factor of development of the concept of the main question of philosophy. The Bulletin of Transbaikal State University. Chita, 2009 (5), P. 196-202. 
7. Menchikov G. P. Spiritual reality of the person (analysis of philosophical and ontologic bases): abstract of the thesis diss. for Dr.s Philosophy. Kazan, 1999, 15 p.

8. Feynman R. Theory of fundamental processes. Moscow, Science, 1978. P. 108-112.

9. Abramov YU.F., Kosolapov R. A., Kuybar V. I. The Phenomenon of Spirituality in the Gglobalizing Society. News of Irkutsk state university. Political science. Religious studies. Irkutsk, 2015(11). P. 169-181.

10. Zinkov E. G. Cultural space of the Russian spirituality: abstract of the thesis diss. for Dr.s Philosophy. Rostov-on-Don, 2006, 42 p.

11. Homuttsov S. V. Spirituality, its similarity and antipodes in culture: abstract of the thesis diss. for Dr.s Philosophy. Barnaul, 2009, 45 p.

12. Kozlova M. V. Spirituality of society in the conditions of globalization: abstract of the thesis diss. for candidate Philosophy. Krasnoyarsk, 2012, 22 p.

\title{
Концепт и структура феномена духовности \\ в современном религиоведении
}

\author{
Р.А. Косолапов, В.И. Куйбарь \\ Иркутский государственный университет \\ Россия, 664003, Иркутск, ул. Карла Маркса, 1
}

В статье дается сочиально-философское понимание природы духовности, которая рассматривается как система устойчивых связей человека и общества, как способ организации и существования цуенностного начала в содержании общечеловеческого бытия. Исследуются его религиозное и светское толкования, методология и эффективность в познании двух типов общества - потребления и созидания - в условиях современной глобализациии.

Ключевые слова: духовность, виртуальная реальность, сочиальное, светское, религчозное, православное мировоззрение, общество потребления, общество созидания, глобализация.

Научная специальность: 09.00.00 - философские науки. 